ESJ Natural/Life/Medical Sciences

\title{
Socioeconomic and Cultural Importance of The Yellow- Fronted Canary (Serinus Mozambicus) in Northern Benin
}

\section{Adoté Hervé Gildas. Akueson}

Department of Natural Resources Management, Doctoral School of Agronomic and Water Sciences, University of Parakou,Parakou, Benin Unit of Applied Statistics and Informatics (USIA), Laboratory of Studies and Research in Forestry (LERF)

\section{Marcel Gbaguidi Alia}

Unit of Applied Statistics and Informatics (USIA), Laboratory of Studies and Research in Forestry (LERF)

\section{Sissou Zakari}

Department of Natural Resources Management, Doctoral School of Agronomic and Water Sciences, University of Parakou,Parakou, Benin Laboratory of Hydraulics and Environmental Modeling (HydroModE-Lab), Faculté d'Agronomie, University of Parakou, Parakou, Benin

Arcadius Yves. Justin. Akossou

Department of Natural Resources Management, Doctoral School of Agronomic and Water Sciences, University of Parakou, Parakou, Benin. Unit of Applied Statistics and Informatics (USIA), Laboratory of Studies and Research in Forestry (LERF)

Doi:10.19044/esj.2021.v17n37p323

Submitted: 07 August 2021

Accepted: 26 October 2021

Published: 31 October 2021
Copyright 2021 Author(s)

Under Creative Commons BY-NC-ND 4.0 OPEN ACCESS

Cite As:

Akueson A.H.G., Gbaguidi Alia M., Zakari S. \& Akossou A.Y.J. (2021). Socioeconomic and Cultural Importance of The Yellow-Fronted Canary (Serinus Mozambicus) in Northern Benin. European Scientific Journal, ESJ, 17(37), 323.

https://doi.org/10.19044/esj.2021.v17n37p323

\section{Abstract}

The species yellow-fronted canary undergoes a real traffic due to its song and medico-magical properties in order to supply local commercial networks. This study aims to assess the socioeconomic and cultural importance of this bird in order to identify the cohorts of actors involved along this activity chain. In this context a survey was carried out among 400 breeders in four agroecological zones of Benin (ZAE II; ZAE III, ZAE IV and ZAE V). 
The questionnaire also focused on general characteristics of the respondents on aspects related to general knowledge of the bird, its social importance, purchase and sale price, cultural importance and breeders’ perceptions. Canary traders, mostly with primary education level (63.25\%) and Muslim (97.5\%), were on average 44 years old and an average experience of 27 years. They exercised this activity in part-time (96.5\%). The knowledge about canary is shared is different depending on the ethnic group. The activity was profitable for all of them (100\%) with 128,624 FCFA (233.18 USD) net profit per month. The trader's education level, whether or not he belonged to ZAE II, the number of birds he had in his possession, the daily amount he invested in their food, their selling price, the number of years he made the activity, his experience in the business were the factors that determine the net profit of the canary's trader. However, canaries' breeding in north-Benin is based on a complex system with actors who develop many myths around medico-magical practices. This study was necessary to better assess the pressure on the species in order to anticipate its conservation.

Keywords: Communities, Knowledge, Profitability, Yellow-Fronted Canary, Benin

\section{Introduction}

\section{Background}

Animals are of social as well as economic interest for people. For example, poultry used in cockfighting and horse used for racing and rodeos. Others like the pangolin present an ethno-zoonic and commercial interest (Zanvo et al., 2021). Thus, animals have a very important place in the daily life of populations and each one values them according to his own feelings (Mongne, 2012). Birds play a very important role in the urbanization of cities (Konan et al. 2014). They are of particular interest in the social sciences (Guillo, 2015). Among these animals, birds are of particular importance and this depending on the use that humans make of them. They are valuable biological indicators for assessing certain types of disturbance in the natural environment (Yabi et al., 2017). They are also the best taxonomic resolution for studying changes in gallery forests (Seymour et al., 2015) and play a very important ecological role by dispersing seeds to ensure the survival of plants (Dorst, 1947). Bird watching has also been translated into mathematical equations for the purposes of scientific research (Markowitz et al., 2013). But it is not uncommon to find that the exploitation of avifauna is carried out blindly, without a clear conscience, without knowledge of the exact social and economic value that it provides ( $\mathrm{Bi}$ et al., 2015). Among these birds, one has the yellow-fronted canary. 
Yellow-fronted canary is mainly sought after for its song. It is used, like the rooster during cockfights. When betting games on the songs of two or more males, breeders look for the bird whose song is the most melodious and which has more so-called "sexy" syllables. Due to this game, breeding this bird becomes an important and popular activity in northern Benin.

In the face of the alarming deterioration of biodiversity, due in large part to human activities, and the observation of global changes, particularly climatic changes, it is imperative and urgent to conserve biodiversity (Gosselin et al., 2006). In fact, humans represent the main force of rapid change affecting livestock systems in general (Darghouth \& Gharbi, 2011). Thus, knowledge of birds like the yellow-fronted canaries must necessarily be done in a participatory manner with grassroots populations in order to better understand their habits and customs and, in turn, to succeed in species conservation (Yaokokore-Beibro et al., 2010).

The conservation of resources is a topical concern and the success of this process requires the provision of a database aimed at enriching the scientific world with information on the biology and demography of most species (Akpona et al., 2007). In Benin, some studies were performed on the ethnozoological knowledge of some bird species (Lougbegnon, 2015), on the biodiversity and ecological distribution of avifauna (Lougbegnon et al., 2007) but no indexing has made any case of the importance of the use of Yellowfronted canaries in sports activities which can generate considerable income. This study provides thus an overview on the use of yellow-fronted canaries as a source of income for the populations of North Benin.

\section{Main Text}

Methods

\section{Study Area}

This study was conducted in the Districts of Bembèrèkè $\left(10^{\circ} 13^{\prime} 30^{\prime}\right.$ ' $\mathrm{N}$, $\left.2^{\circ} 40^{\prime} 05^{\prime \prime} \mathrm{E}\right)$, Djougou $\left(9^{\circ} 42^{\prime} 00^{\prime \prime} \mathrm{N}, 1^{\circ} 40^{\prime} 00^{\prime \prime} \mathrm{E}\right)$, Kalalé $\left(10^{\circ} 12^{\prime} 47^{\prime}{ }^{\prime} \mathrm{N}\right.$,

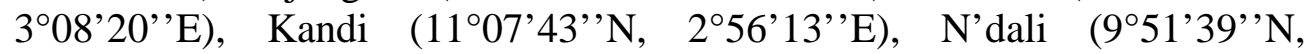

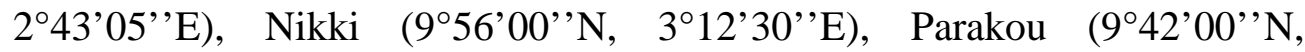
$\left.1^{\circ} 40^{\prime} 00^{\prime \prime} \mathrm{E}\right)$ and Tchaourou ( $\left.8^{\circ} 53^{\prime} 00^{\prime \prime} \mathrm{N}, 2^{\circ} 36^{\prime} 00^{\prime \prime} \mathrm{E}\right)$. These localities are distributed in four agroecological zones in the Northern Benin (Figure 1). We chose these areas on the basis of their proximity with dense vegetation and watercourses. The presence of associations of breeders of this bird in the different agroecological zones was also considered. A total of eleven (11) sites were selected for the present study, and the sites spread across the eight (8) municipalities (Table 1).

The region of Kandi has a Sudanese climate with a dry season (November to April) and a rainy season (May to October). The region of Bembèrèkè, on the other hand, has a south-Sudanese continental climate 
which gradually changes to the North Sudanese type in the far north. This climate is characterized by the succession in the year of a dry season (November to March) and a rainy season (May to October with maximums between July and August). The region of Kalalé has a savannah climate with much more rainfall in summer than in winter. N'dali has a lot of rainfall in the dry season than the rainy season, with an estimated average temperature of $26.8^{\circ} \mathrm{C}$ (over the year) and an average of $1023.6 \mathrm{~mm}$ of rainfall. In the region of Nikki, the rainy season is oppressive and overcast while the dry season is partly cloudy and the climate is very hot throughout the year. The region of Djougou is characterized by a savannah climate. As for Parakou, the dry season is humid and partly cloudy and the climate is very hot throughout the year, with a temperature varying from $17^{\circ} \mathrm{C}$ to $39^{\circ} \mathrm{C}$ during the year. In Tchaourou, the dry season is wet and partly cloudy and the climate is very hot throughout the year.

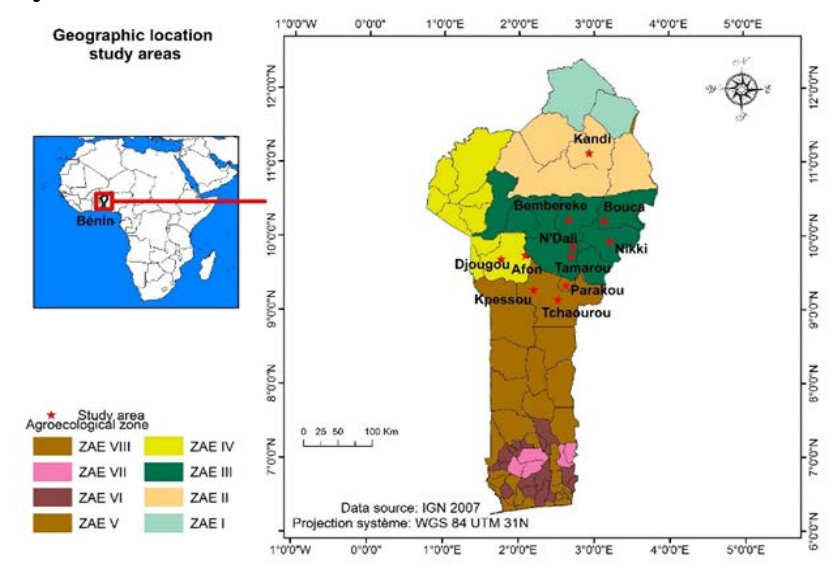

Figure 1. Map showing municipalities under study

Table 1. Locations visited by department

\begin{tabular}{|c|c|c|c|}
\hline Departments & $\begin{array}{c}\text { Municipality / } \\
\text { Areas }\end{array}$ & Sites & $\begin{array}{c}\text { Overall } \\
\text { interviewed }\end{array}$ \\
\hline Alibori & Kandi & Kandi Centre & 50 \\
\hline \multirow[t]{8}{*}{ Borgou } & Bembèrèkè & $\begin{array}{l}\text { Bembèrèkè } \\
\text { Centre }\end{array}$ & 50 \\
\hline & \multirow[t]{2}{*}{ N'dali } & N'dali Centre & 30 \\
\hline & & Tamarou & 20 \\
\hline & Nikki & Nikki Centre & 50 \\
\hline & Kalalé & Bouca & 50 \\
\hline & Parakou & Parakou Centre & 50 \\
\hline & \multirow[t]{2}{*}{ Tchaourou } & Sanson & 25 \\
\hline & & Kpéssou & 25 \\
\hline \multirow[t]{2}{*}{ Donga } & \multirow[t]{2}{*}{ Djougou } & Afon & 20 \\
\hline & & Djougou Centre & 30 \\
\hline \multicolumn{3}{|c|}{ Overall } & 400 \\
\hline
\end{tabular}




\section{Data Collection}

According to the methodology of $\mathrm{Bi}$ et al. (2015), the present study carried out a field survey from November 2019 to January 2020. Four hundred (400) people were purposely selected from the sampling sites (Table 1) were interviewed using semi-structured interviews with the breeders and direct observations in the breeders' houses. Apart from few people, the interviews were mostly done with groups of 4 to 5 breeders, without interference of the interviewer in the interlocutors' answers. A questionnaire considered aspects related to the general knowledge of yellow-fronted canaries, its social importance, its economic importance, its cultural importance and the perception of breeders on the breeding of yellow-fronted canaries. We used a flexible guide question checklist where new questions or lines of inquiry emerged throughout the interview.

\section{Data Analysis}

The data analysis was performed using R statistical software (Version 4.0.0, R Core Team, 2020). The socio-professional characteristics were described using descriptive statistics tools (frequencies, means and coefficients of variation). Chi-square test was performed to check the relationship between different forms of knowledge sharing and sociolinguistic groups. Correspondence analysis (CA) was then carried out on these two variables using the following R packages: corrplot (Wei \& Simko, 2017), ggplot2 (Wickham, 2016), FactoMineR (Lê et al., 2008) and factoextra (Kassambara \& Mundt, 2020). The traders' operating account was established to analyze the commercial margins of canary's farmers in the different municipalities. The net margin of each trader was estimated using the following formula:

$$
\begin{aligned}
& \mathrm{MN}_{\mathrm{i}}=100 \times \frac{\mathrm{PN}_{\mathrm{i}}}{\mathrm{CA}_{\mathrm{i}}} \\
& \text { With } \mathrm{CA}_{\mathrm{i}}=\mathrm{PV}_{\mathrm{i}} \times \mathrm{NV}_{\mathrm{i}} \text { and } \mathrm{PN}_{\mathrm{i}}=\mathrm{CA}_{\mathrm{i}}-\mathrm{CT}_{\mathrm{i}}
\end{aligned}
$$

Where, $\mathrm{MN}_{\mathrm{i}}=$ Net margin of the $\mathrm{i}$-th trader, $\mathrm{PN}_{\mathrm{i}}=$ Net Profit of the $\mathrm{i}$ th trader, $\mathrm{CA}_{\mathrm{i}}=$ Turnover of the $\mathrm{i}$-th trader, $\mathrm{PV}_{\mathrm{i}}=$ Average selling price of $\mathrm{a}$ bird by the $\mathrm{i}$-th trader, $\mathrm{NV}_{\mathrm{i}}=$ Number of birds sold by the i-th trader, and $\mathrm{CT}_{\mathrm{i}}=$ Total charges of the $\mathrm{i}$-th trader

Mean comparisons were computed using Student Newman-Keuls (SNK) test with agricolae package (de Mendiburu, 2020). A multiple linear regression model was fitted, combining variable selection method, to determine the factors that influence the net profit generated by the sale of canary. Finally, the frequency histograms were used to bring out the perceptions of the respondents on the different characteristics of the canary. 


\section{Results}

\section{Characterization of yellow-fronted canary traders according to municipality}

The analysis of the socio-professional characteristics of the traders (Table 2) revealed that the majority of traders (63.25\%) reached primary school except in Tchaourou where most of them (80\%) had no level of education, but attended Koranic school in a literacy class. The traders were mostly married (94.25\%) and belonged to Muslim religion (97.5\%). They breed and sell canary as a secondary activity (96.5\%), and were on average 44 years old with around 27 years of experience in this activity. The comparisons show that the traders from Kandi were significantly older than those of the other municipalities ( $p<0.05$, Table 3 ). The traders from Kandi also had more birds and professional experience compared to those from the other municipalities. $(p<0.05$, Table 3$)$.

Table 2. Qualitative characteristics (frequencies in \%) of respondents following the municipality

\begin{tabular}{|c|c|c|c|c|c|c|c|c|c|}
\hline Variables & Bembèrèkè & Djougou & Kalalé & Kandi & N'dali & Nikki & Parakou & Tchaourou & Overall \\
\hline \multicolumn{10}{|c|}{ Educational level } \\
\hline None & 6 & 12 & 2 & 10 & 16 & 20 & 14 & 80 & 20.00 \\
\hline Primary & 92 & 48 & 78 & 72 & 66 & 74 & 56 & 20 & 63.25 \\
\hline $\begin{array}{l}\text { Middle / } \\
\text { high } \\
\text { school }\end{array}$ & 2 & 28 & 16 & 14 & 12 & 2 & 20 & - & 11.75 \\
\hline University & - & 12 & 4 & 4 & 6 & 4 & 10 & - & 5.00 \\
\hline \multicolumn{10}{|c|}{ Non-formal education } \\
\hline $\begin{array}{c}\text { Literacy } \\
\text { class }\end{array}$ & 60 & - & 30 & 10 & 30 & 10 & 12 & 100 & 31.50 \\
\hline $\begin{array}{c}\begin{array}{c}\text { Koranic } \\
\text { school }\end{array} \\
\end{array}$ & 96 & 8 & 100 & 100 & 100 & 96 & 12 & 100 & 76.50 \\
\hline \multicolumn{10}{|c|}{ Marital status } \\
\hline Single & 10 & 4 & 12 & - & 2 & - & 16 & 2 & 5.75 \\
\hline Married & 90 & 96 & 88 & 100 & 98 & 100 & 84 & 98 & 94.25 \\
\hline \multicolumn{10}{|c|}{ Religion } \\
\hline Animist & - & - & - & 6 & - & - & - & - & 0.75 \\
\hline Christian & - & - & - & 6 & - & - & 2 & 6 & 1.75 \\
\hline Muslim & 100 & 100 & 100 & 88 & 100 & 100 & 98 & 94 & 97.50 \\
\hline \multicolumn{10}{|c|}{ Ethnic group } \\
\hline Bariba & 98 & 10 & 50 & 22 & 86 & 100 & 80 & 80 & 65.75 \\
\hline Dendi & - & 42 & - & 54 & 14 & - & 6 & 6 & 15.25 \\
\hline Boo & - & - & 50 & - & - & - & - & - & 6.25 \\
\hline Yom & - & 36 & - & - & - & - & 2 & - & 4.75 \\
\hline Mokollé & - & - & - & 24 & - & - & - & - & 3.00 \\
\hline Others $(*)$ & 2 & 12 & - & - & - & - & 12 & 14 & 5.00 \\
\hline
\end{tabular}




\begin{tabular}{|c|c|c|c|c|c|c|c|c|c|}
\hline Breeders & - & 10 & - & 14 & 2 & - & 2 & - & 3.50 \\
\hline $\begin{array}{c}\text { Non } \\
\text { breeders }\end{array}$ & 100 & 90 & 100 & 86 & 98 & 100 & 98 & 100 & $\mathbf{9 6 . 5 0}$ \\
\hline
\end{tabular}

Note: Others $(*)=$ Ethnic groups represented by less than 10 individuals in the sample (Yoruba, Lokpa, Fon, Adja, Otamari)

Table 3. Quantitative characteristics (mean and coefficient of variation $=\mathrm{CV}$ in \%) of respondents following the municipality

\begin{tabular}{|c|c|c|c|c|c|c|c|c|c|}
\hline Variables & & Bembereke & Djougou & Kalale & Kandi & Ndali & Nikki & Parakou & Tchaourou \\
\hline \multirow[t]{2}{*}{ Age } & Mean & $40.68^{\mathrm{c}}$ & $47.64^{\mathrm{b}}$ & $40.92^{\mathrm{c}}$ & $54.06^{\mathrm{a}}$ & $37.76^{\mathrm{c}}$ & $46.14^{\mathrm{b}}$ & $48.42^{\mathrm{b}}$ & $36.04^{\mathrm{C}}$ \\
\hline & $\begin{array}{l}\text { CV } \\
(\%)\end{array}$ & 26.80 & 23.47 & 24.21 & 19.90 & 25.95 & 16.43 & 28.28 & 28.95 \\
\hline \multirow[b]{2}{*}{$\begin{array}{l}\text { Number } \\
\text { of } \\
\text { residence } \\
\text { years in } \\
\text { area }\end{array}$} & Mean & $38.66^{\mathrm{b}}$ & $45.32^{\mathrm{a}}$ & $39.30^{\mathrm{b}}$ & $43.76^{\mathrm{a}}$ & $37.28^{b}$ & $45.30^{\mathrm{a}}$ & $45.92^{\mathrm{a}}$ & $34.74^{\mathrm{b}}$ \\
\hline & $\begin{array}{l}\mathrm{CV} \\
(\%)\end{array}$ & 27.80 & 25.00 & 24.85 & 24.25 & 27.45 & 17.47 & 29.19 & 27.42 \\
\hline \multirow{2}{*}{$\begin{array}{l}\text { Number } \\
\text { of birds in } \\
\text { possession }\end{array}$} & Mean & $13.82^{\mathrm{cd}}$ & $11.92^{\text {cde }}$ & $21.28^{\mathrm{b}}$ & $29.54^{\mathrm{a}}$ & $14.70^{c}$ & $12.28^{\text {cde }}$ & $10.52^{\mathrm{e}}$ & $11.42^{\mathrm{de}}$ \\
\hline & $\begin{array}{l}\text { CV } \\
(\%)\end{array}$ & 32.45 & 34.09 & 23.10 & 41.20 & 21.65 & 20.15 & 33.11 & 26.85 \\
\hline \multirow{2}{*}{$\begin{array}{c}\text { Number } \\
\text { of years in } \\
\text { the } \\
\text { activity }\end{array}$} & Mean & $23.96^{\text {cd }}$ & $31.78^{\mathrm{ab}}$ & $26.94^{\text {bcd }}$ & $34.58^{\mathrm{a}}$ & $22.22^{\mathrm{d}}$ & $27.80^{\mathrm{bc}}$ & $30.24^{\mathrm{ab}}$ & $17.72^{\mathrm{e}}$ \\
\hline & $\begin{array}{l}\mathrm{CV} \\
(\%)\end{array}$ & 42.56 & 36.68 & 34.24 & 38.93 & 41.82 & 28.22 & 42.77 & 49.33 \\
\hline \multirow{2}{*}{$\begin{array}{c}\text { Number } \\
\text { of } \\
\text { working } \\
\text { days per } \\
\text { week }\end{array}$} & Mean & $7.00^{\mathrm{a}}$ & $6.08^{c}$ & $7.00^{\mathrm{a}}$ & $6.92^{\mathrm{a}}$ & $7.00^{\mathrm{a}}$ & $6.48^{\mathrm{b}}$ & $6.58^{\mathrm{ab}}$ & $6.68^{\mathrm{ab}}$ \\
\hline & $\begin{array}{l}\mathrm{CV} \\
\text { (\%) }\end{array}$ & 0.00 & 22.99 & 0.00 & 4.87 & 0.00 & 16.40 & 15.53 & 15.97 \\
\hline
\end{tabular}

The values on the same line, followed by the same letters, were not significantly different at the level of 5\% following the test of means comparison.

\section{Local names of yellow-fronted canary and meaning}

Yellow-fronted canary was well known by the local populations of the study area. The name of the species varied from one ethnic group to another (Table 4). It was generally called Tita by Bariba,Boo, Dendi, Mokollé, Ibaka by Yoruba, and even canary by Fon and Bariba. For other ethnic groups, the common name of canaries changes according to ethnic groups

Table 4. Local names of yellow-fronted canary and their meanings according to sociolinguistic groups

\begin{tabular}{|c|c|c|}
\hline $\begin{array}{c}\text { Sociolinguistic } \\
\text { groups }\end{array}$ & Local names & Meanings \\
\hline $\begin{array}{c}\text { Bariba, } \\
\text { Yoruba }\end{array}$ & $\begin{array}{c}\text { Gbèdikou/Tita } \\
\text { Ibaka }\end{array}$ & $\begin{array}{c}\text { Which likes millet } \\
\text { Which likes millet }\end{array}$ \\
\hline Fon & Serin/Agbolivi & Which sings well \\
\hline Boo, & Ti taê/Effekaénan \\
Tita/Boulangakiro & $\begin{array}{c}\text { Bird with powerful melodies/millet } \\
\text { destroyed Bird }\end{array}$ \\
\hline
\end{tabular}




\begin{tabular}{|c|c|c|}
\hline & & $\begin{array}{c}\text { Bird with powerful melodies/ Bird of } \\
\text { Vitellaria Paradoxa }\end{array}$ \\
\hline Adja, & Hévi & Which sings well \\
\hline Mokollé & Tita/Kiro & Which sings in the rainy season \\
\hline Lokpa, & Kome & $\begin{array}{c}\text { Birds very useful } \\
\text { Otamari, } \\
\text { Yom }\end{array}$ \\
Inorbi & Tamgnira & $\begin{array}{c}\text { Which sings during the shea season } \\
\text { and eat fonio } \\
\text { Bird of Vitellaria Paradoxa }\end{array}$ \\
\hline
\end{tabular}

\section{Sociocultural importance of canary in the Northern Benin}

Regarding to the cultural practices, the figure 2a shows that among the ethnic groups Otamari, Lokpa, Yom, and Fon, more than $50 \%$ of the population use yellow-fronted canary, unlike the ethnic groups Yorouba, Dendi, Bariba, Mokole and Boo. The knowledge acquirement about Yellowfronted canary (figure $2 \mathrm{~b}$ ) was mainly by inheritance or gift $(65.3 \%)$ and curiosity or self-learning (29.8\%). Most of the families were native (96.3\%, figure 2c) and this bird is used in traditional practices (29.5\%, figure $2 \mathrm{~d}$ ) such as helping a child who does not speak quickly, starting with do it; for an adult to have a speech that catches the attention of his audience; the feathers would attract good luck; to be successful when you request a service or you go to your creditor or you apply for a post; during a long trip, a feather would protect you from possible road accidents. A large part of the captured yellow-fronted canaries were also used for singing competitions (62\%, figure $2 \mathrm{~d}$ ), to see the bird with the most melodious song and resorting to a duel (figures $3 a$ and $3 b$ ).
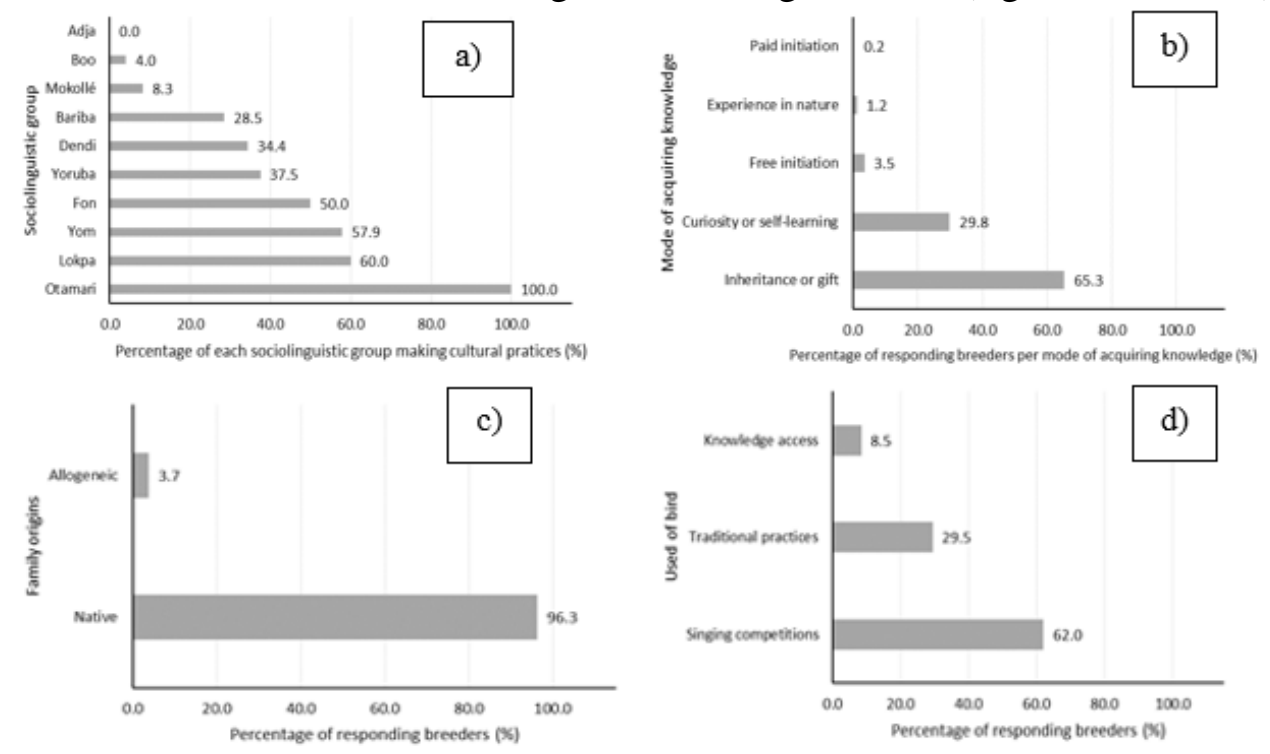

Figure 2. Cultural value and characteristics of knowledge about the Yellow-fronted canaries: a) proportions of each sociolinguistic group making cultural practices; b) mode of acquiring knowledge; c) family origins; d) used of the bir 


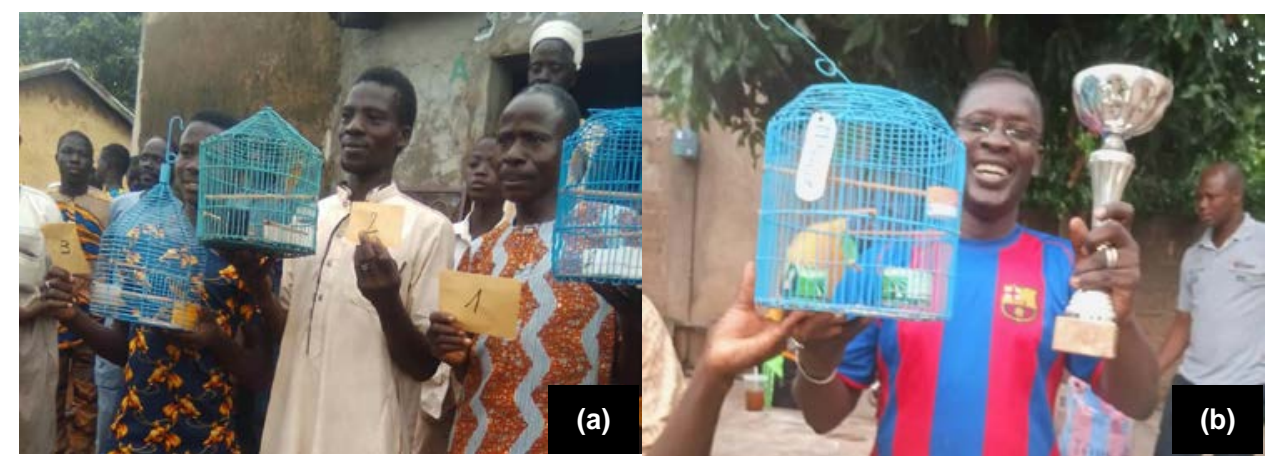

Figure 3. Winners of the Yellow-fronted canaries singing competitions

In order to summarize and visualize the relationships between the sociolinguistic groups and the different forms of knowledge sharing (regarding the canary) as well as origins and mode of acquiring knowledge, the Multiple Correspondence Analysis (MCA) was performed (Figure 4). It emerges that the sociolinguistic groups Lokpa and Otamari from Djougou acquire their knowledge about the canary mainly through paid initiation; the sociolinguistic groups Adja, Boo, Fon, bariba, yoruba and Lokpa from Parakou, Ndali, Nikki, Tchaourou and Bembereke acquire their knowledge about the Canary mainly through curiosity or self-learning; finally the sociolinguistic groups Dendi and Mokollé from Kandi acquire this knowledge mainly through inheritance or gift or free initiation. In addition, the ethnics Adja and Fon share the acquired knowledge on the Canary with their close relative, children, parents, family and friends. The ethnics Lokpa, Yom and Otamari share them with their relatives, parents, family and friends. Boo and Mokollé share them with their children, parents and family. Bariba do it with their children while Dendi do it with their family. As for the Yoruba, they share this knowledge with their children and parents. 


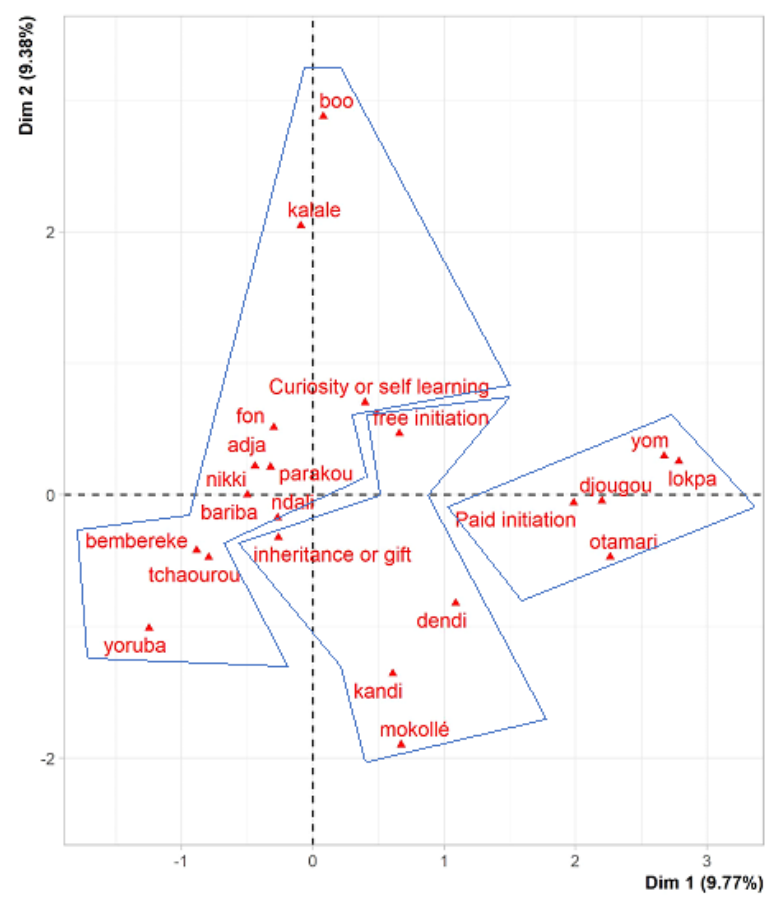

Figure 4. Relationship between knowledge sharing about the canary and ethnic groups in the first factorial map

\section{Analysis of the trade margins of Canary farmers in the municipalities of northern Benin}

The number of canary sold, their selling price, gross income, overall costs and the net profit of traders in the municipality of Kandi were significantly higher than those in other municipalities ( -value $<0.05)$ (table 5). However, the estimated net margin for traders in the municipality of Kandi was similar to that of traders in the municipalities of Bembèrèkè, N'dali, Nikki and Tchaourou. The average profit per month from the sale of canary was $128,624 \mathrm{FCFA}$ in the study area.

Table 5. Monthly operating accounts of traders according to agroecological zones

\begin{tabular}{|c|c|c|c|c|c|c|c|c|c|}
\hline Variables & & Bembèrèkè & Djougou & Kalalé & Kandi & N'dali & Nikki & Parakou & Tchaourou \\
\hline \multirow{2}{*}{$\begin{array}{l}\text { Quantity } \\
\text { sold }\end{array}$} & Mean & $5.46^{\mathrm{cd}}$ & $4.80^{\mathrm{d}}$ & $8.76^{\mathrm{b}}$ & $11.40^{\mathrm{a}}$ & $6.74^{\mathrm{bc}}$ & $7.42^{b}$ & $7.96^{\mathrm{b}}$ & $8.38^{\mathrm{b}}$ \\
\hline & $\begin{array}{l}\mathrm{CV} \\
(\%)\end{array}$ & 63.78 & 44.29 & 45.69 & 67.74 & 38.21 & 35.36 & 38.84 & 31.83 \\
\hline \multirow{2}{*}{$\begin{array}{l}\text { Sale price } \\
\text { (in } \\
\text { thousands } \\
\text { of FCFA) }\end{array}$} & Mean & $27.40^{\mathrm{b}}$ & $6.80^{\mathrm{f}}$ & $15.60^{c}$ & $33.60^{\mathrm{a}}$ & $15.98^{\mathrm{c}}$ & $10.68^{\mathrm{de}}$ & $13.36^{\text {cd }}$ & $8.00^{\mathrm{ef}}$ \\
\hline & $\begin{array}{l}\text { CV } \\
(\%)\end{array}$ & 38.32 & 25.47 & 47.22 & 28.86 & 46.40 & 91.83 & 45.21 & 29.92 \\
\hline \multirow{3}{*}{$\begin{array}{c}\text { Gross } \\
\text { income } \\
\text { (thousands } \\
\text { FCFA) }\end{array}$} & Mean & $139.90^{\mathrm{b}}$ & $30.12^{\mathrm{d}}$ & $144.21^{\mathrm{b}}$ & $374.80^{\mathrm{a}}$ & $103.38^{\mathrm{bc}}$ & $80.60^{\text {bcd }}$ & $107.60^{\mathrm{bc}}$ & $67.67^{\mathrm{cd}}$ \\
\hline & $\begin{array}{l}\text { CV } \\
\text { (\%) }\end{array}$ & 67.54 & 31.26 & 79.48 & 73.59 & 48.01 & 93.43 & 61.34 & 50.98 \\
\hline & Mean & $2.81^{\mathrm{c}}$ & $1.52^{\mathrm{e}}$ & $3.29^{b}$ & $3.69^{\mathrm{a}}$ & $2.00^{\mathrm{d}}$ & $1.51^{\mathrm{e}}$ & $3.23^{b}$ & $1.26^{f}$ \\
\hline
\end{tabular}




\begin{tabular}{|c|c|c|c|c|c|c|c|c|c|}
\hline $\begin{array}{c}\text { Overall } \\
\text { charge } \\
\text { (thousands } \\
\text { FCFA) }\end{array}$ & $\begin{array}{l}\text { CV } \\
\text { (\%) }\end{array}$ & 9.80 & 33.99 & 14.48 & 15.13 & 18.36 & 32.68 & 17.13 & 37.59 \\
\hline \multirow{2}{*}{$\begin{array}{l}\text { Estimated } \\
\text { net margin } \\
\text { (in \%) }\end{array}$} & Mean & $97.40^{\mathrm{a}}$ & $94.22^{b}$ & $95.16^{\mathrm{b}}$ & $98.24^{\mathrm{a}}$ & $97.45^{a}$ & $97.22^{\mathrm{a}}$ & $95.46^{\mathrm{b}}$ & $97.79^{\mathrm{a}}$ \\
\hline & $\begin{array}{l}\text { CV } \\
(\%)\end{array}$ & 1.24 & 3.52 & 6.98 & 1.54 & 1.68 & 1.97 & 3.53 & 1.30 \\
\hline \multirow{2}{*}{$\begin{array}{l}\text { Net profit } \\
\text { (thousands } \\
\text { FCFA) }\end{array}$} & Mean & $137.09^{b}$ & $28.60^{\mathrm{d}}$ & $140.93^{b}$ & $371.11^{\mathrm{a}}$ & $101.38^{\mathrm{bc}}$ & $79.09^{\text {bcd }}$ & $104.37^{\mathrm{bc}}$ & $66.42^{\mathrm{cd}}$ \\
\hline & $\begin{array}{l}\text { CV } \\
(\%)\end{array}$ & 68.90 & 32.96 & 81.25 & 74.27 & 49.04 & 95.16 & 63.25 & 51.85 \\
\hline
\end{tabular}

The values of the same line, followed by the same letters, were not significantly different at the level of $5 \%$ following the test of means comparison, $C V=$ Variation coefficient

\section{Determinants of the net profit generated by the sale of canary in the agroecological zones of North Benin}

The outputs of the regression model estimated to identify the determinants of the net profit of canary traders, are presented in Table 6 . Analysis of this table showed that the regression model was highly significant (p-value $<0.001$ ). Thus, $52.75 \%$ of the variations in the net profit of the traders surveyed were explained by the variations of the variables introduced into the model. The results obtained indicated that two qualitative variables (ZAE II and niv_instr) have a significant effect (p-value < 0.001) on the seller's net profit. Thus, the profit depends on the one hand on whether or not it belongs to agroecological zone II and, on the other hand, on whether or not having received an educational instruction. According to the quantitative variables, the average selling price and the daily amount invested in food were significant. In addition, the number of birds in possession had a positive and significant effect ( $p$-value $<0.05$ ) on the net profit of the seller.

Table 6. Determinants of net profit from canary sale: results of the multiple linear regression model

\begin{tabular}{|c|c|c|c|c|c|}
\hline Variables & Description & Estimate & $\begin{array}{l}\text { Standard } \\
\text { error }\end{array}$ & t-value & p-value \\
\hline \multicolumn{6}{|l|}{ Intercept } \\
\hline AEZ2 & $\begin{array}{l}\text { Belonging to } \\
\text { agroecological zone II ( } 0 \\
=\text { no, } 1=\text { yes })\end{array}$ & 99728.76 & 24458.22 & 4.08 & $\begin{array}{r}< \\
0.001\end{array}$ \\
\hline niv_instr & $\begin{array}{l}\text { Education level }(0=\text { none, } \\
\qquad 1=\text { other })\end{array}$ & -35657.46 & 13856.53 & -2.57 & 0.010 \\
\hline nb_oiseau & $\begin{array}{c}\text { Number of birds in } \\
\text { possession }\end{array}$ & 2293.46 & 862.57 & 2.66 & 0.008 \\
\hline prix_moy_vente & $\begin{array}{l}\text { Average selling price of } \\
\text { the species in FCFA }\end{array}$ & 5.97 & 0.56 & 10.64 & $\begin{array}{r}< \\
0.001\end{array}$ \\
\hline mont_invest_alim_jr & $\begin{array}{l}\text { Daily amount invested in } \\
\text { food in FCFA }\end{array}$ & 2303.56 & 649.11 & 3.55 & $\begin{array}{r}< \\
0.001\end{array}$ \\
\hline Response variable & $\begin{array}{l}\text { Net profit of the trader in } \\
\text { FCFA }\end{array}$ & & & & \\
\hline
\end{tabular}




\begin{tabular}{|c|c|l|l|l|l|}
\hline $\begin{array}{c}\text { Number of } \\
\text { observations }\end{array}$ & 400 & & & & \\
\hline $\begin{array}{c}\text { Fisher's F statistic } \\
\text { (F value) }\end{array}$ & 62.53 & & & & \\
\hline $\begin{array}{c}\text { Degrees of freedom } \\
\text { (DFs) }\end{array}$ & $\begin{array}{c}\text { (DF1 }=7 \text { DF2 } \\
\text { 392) }\end{array}$ & & & & \\
\hline p-value & $<0.001$ & & & & \\
\hline $\begin{array}{c}\text { Adjusted coefficient } \\
\text { of determination } \\
\left(\mathrm{R}^{2} \mathrm{a}\right)\end{array}$ & 0.5275 & & & & \\
\hline
\end{tabular}

\section{Perceptions of breeders on the characteristics of the canary}

The majority of respondents declared that Canary coexisted with the tit (35.5\%) and the sparrow (33.5\%) closed to rivers (Figure 5a). In the rainy season it was also present in watercourse (31.8\%) and gallery forests (29.8\%) (Figure 5b) while in the dry season it was found in watercourse $(21.6 \%)$ and bush (21.1\%) (Figure 5c). It fed mainly on sand, grasses, insects, fruits and leaves $(19.9 \%$, figure $5 \mathrm{~d})$. Its predators were mainly raptors and reptiles (43.1\%, figure 5e). It preferably nested on plant species of the following taxonomic genera: Vitellaria sp (38.2\%), Parkia sp (37.4\%) and Gmelina sp (22.7\%) (Figure 5f). Its nesting period took place during the rainy season (49.9\%) or shortly before (44.2\%) (Figure $5 \mathrm{~g}$ ). Finally, when he sings, the frequency peaks in the time slots were noted from 8 am to $12 \mathrm{pm}(25.8 \%)$ and from $3 \mathrm{pm}$ to $5 \mathrm{pm}$ (22.3\%) (Figure $5 \mathrm{~h}$ ).

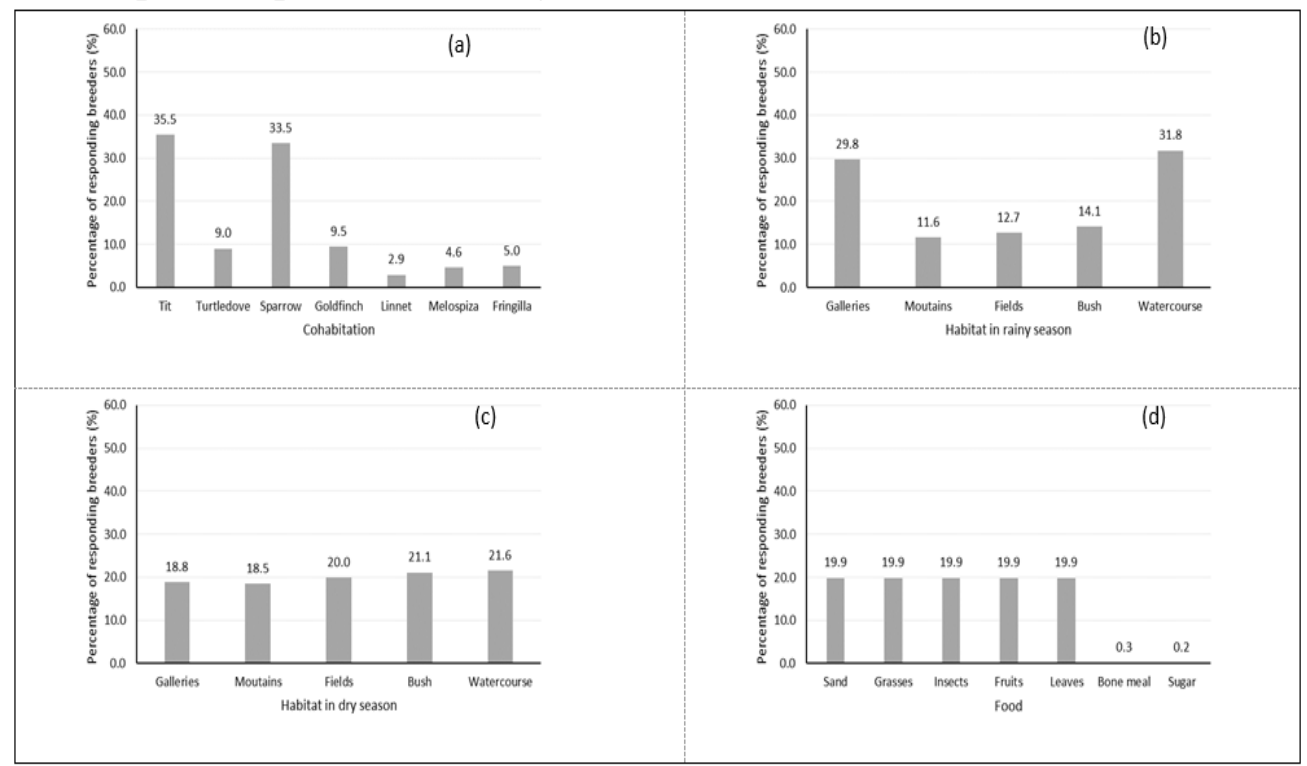




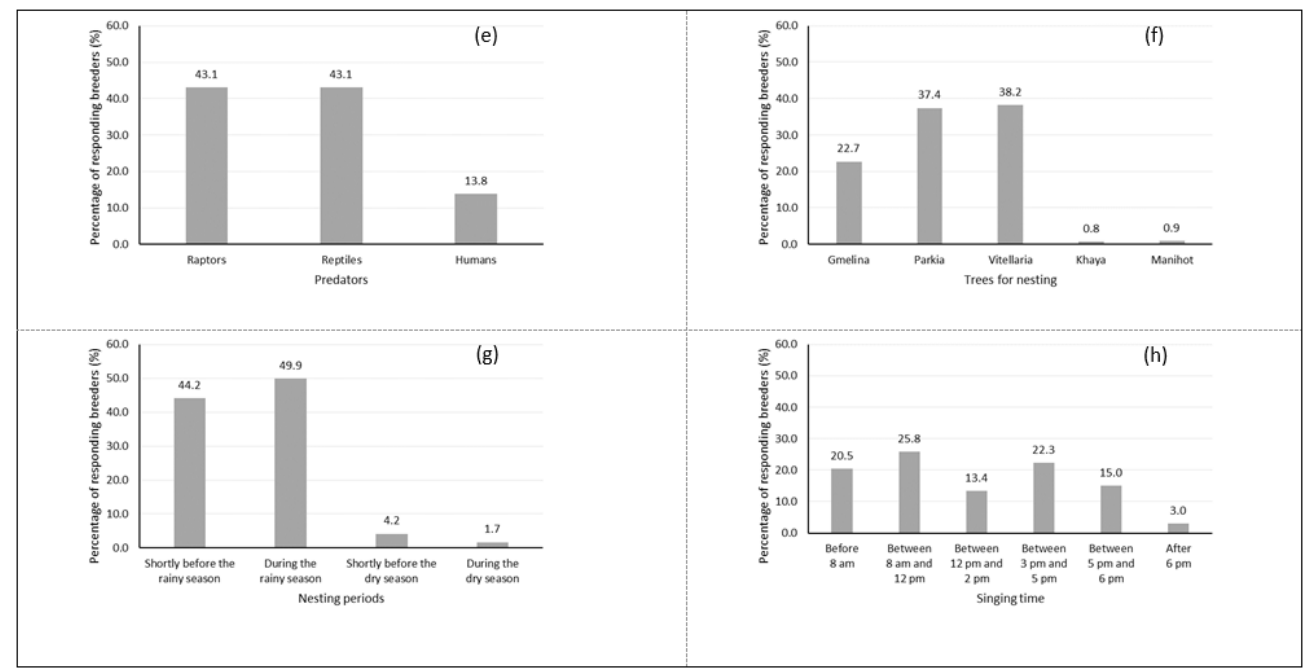

Figure 5. Perceptions of breeders on the characteristics of the canary : $(\mathrm{a}=$ cohabitation; $\mathrm{b}=$ habitat in rainy season; $c$ = habitat in dry season; $d=$ food, $e=$ predators; $f=$ trees for nesting; $\mathrm{g}=$ nesting periods; $\mathrm{h}=$ singing periods)

\section{Discussion}

Biodiversity in general and for birds in particular play an important role in the functioning of ecosystems and in the economic and social life of populations around the world. According to Blendel and Desmet (2018), as research models, birds have contributed more than any other group of animals to the construction of our knowledge of evolution, biogeography, ecology and systematics. On the other hand, if there is one area of knowledge about which we do not know much, it is that of the direct and indirect advantages and benefits that they provide us in everyday life, but also of the prejudices that they can sometimes cause us (Blendel and Desmet, 2018).

In Benin, the literature gives no information on the socio-economic and social importance of yellow-fronted canary. This fact can be explained by the myth that surrounds the breeding of the species, especially in the medicomagical field, thus making this breeding an activity generally reserved for insiders. Yellow-fronted canary is a bird species well known by the populations of the study area. The latter have a great deal of knowledge about the species (type of predator, nesting period, period of vocal intensity, type of habitat, type of diet, birds with which it cohabits). This is reflected in the local names that have been attributed to the species, often relating to its habitat, season of abundance, type of diet and vocal strength. In fact according to Mongne (2012) the names of birds are composed of associated roots (according to the agglutinant principle of the tongue) resulting from the description of the animal: appearance, color of the feathers, cry, gait, flight, food and habitat. With a few exceptions, the canary is referred to as "Tita" by 
most ethnic groups in the study area although these groups come from different geographic areas. This is contrary to the assertions of Sanni et al (2017) and Zanvo et al (2021) who think that the uniformity of common names among ethnic groups located within the same geographic region could be due to the genealogical relationships between the sampled ethnic groups, which originate from the same ancestors and share similar languages. This uniformity could rather be explained by the demographic dominance of the Bariba and Dendi ethnic groups and by whom the first breeding was started and who very early attributed this vernacular name to the canary. Thus, other ethnic groups who probably had no knowledge of the animal were forced to adopt this term "Tita".

The knowledge listed by the local populations corroborates that mentioned by (Fry and Keith, 2004; Sinclair and Hockey, 1996). Indeed, according to Fry and Keith (2004), yellow-fronted canary prefers open woodlands and grasslands below $2300 \mathrm{~m}$, but may also be found in a variety of other habitats including coastal scrub, mangroves, and sand dunes. They frequent cultivated lands where they take advantage of abundant sorghum, millet, and other grains. In terms of food, yellow-fronted canary feed primarily on seeds and insects. Termites, aphids, grasshoppers, and other insects are especially important during the breeding season when chicks demand a relatively high-protein diet. Other food items include leaves, fruit, petals, and nectar.

The knowledge of this bird, as well as its way of life by these ethnic groups can also be explained by the cohabitation and the transmission of endogenous knowledge between these groups evolving in the same geographical area for years on the one hand, and by the wide distribution of the species in its range on the other hand (Habou et al., 2020). The vast majority of actors operating in the exploitation of yellow-fronted canary in northern Benin do so primarily because of singing and secondly because of traditional practices. Unlike some species such as the pangolin, where it is the meat that is used in traditional medicine (Boakye et al 2014), in yellow-fronted canary it is feathers or parts of organs such as the tongue that enter into medicinal and magical compositions. This knowledge of animals by local populations has been highlighted by other authors, notably Yaokokore et al. (2010) who, by studying the ethnozoology of the mammalogical fauna of the Badenou classified forest, were able to show that the populations at the base have a very in-depth knowledge of the fauna in their environment. The methods of acquiring knowledge mentioned by the populations are, among others, transmission by inheritance, self-learning and initiation.

In the area of the present study, the invitation to capture yellow-fronted canary is made at a relatively advanced age (ie an average of 17 years). This is contrary to the assertions of $\mathrm{Bi}$ et al. (2015), who believe that the first contact 
with animals, especially birds, occurs during childhood for the vast majority. The advanced age relative to first contact with the species can be explained by the fact that the latter is a very dressed and small species. This, therefore requires a certain maturity to be able not only to observe it, but also to capture it in the wild and take care of it. This relatively advanced age that breeders reach before embarking on this activity is an advantage for the protection of the species, because it helps to reduce anthropogenic pressure on it and to anticipate possible threats. Indeed, yellow-fronted canaries are categorized as a species of least concern on the IUCN Red List and a CITES Appendix III species. This classification is designed to "prevent or restrict exploitation" which, in this case, may result from excessive capture for the pet trade. Yellow-fronted canary also plays an important ecologically and economically role. Indeed, yellow-fronted canaries are important as seed predators and may act as prey for small raptors, snakes, and small, carnivorous mammals. Yellow-fronted canaries are a popular cagebird throughout the world. Yellowfronted canaries may assist in controlling insect numbers around cultivated fields (Fry and Keith, 2004). However, Yellow-fronted canaries frequently feeds on cultivated grains. Although abundant and widespread, yellow-fronted canary generally forage in small groups and thus never threaten to wipe out a crop, but consistent feeding in farmlands may contribute to lower crop harvests.

Yellow-fronted canary is marked in the habits and customs of the Otamari, Lokpa, Yom, and Fon ethnic groups. The fact that most breeders have a minimum of education allows a form of protection of the animal, because the latter protect the animal against any slaughter, but instead opt for its breeding because of their song, which they believe would be, very therapeutic for humans.

The breeding of yellow-fronted canary has thus become an important activity in northern Benin. In addition to the socio-cultural aspects, the species is mainly sought after for its song. Thus, the most captured specimens are mostly young males due to their song. Because it's the young males can who sing mainly. Its importance due to the high profit that the local populations derive from it. This constitutes additional income and allows them to meet the various needs of their family. This activity takes on its importance especially in certain categories which do so to counter the drop in yield due to the effects of climate change. However, the activity is more important and generates more profit in agroecological zone II (Kandi municipality). This is linked to the abundance of the species in the area and would be due to environmental conditions and a much more diversified diet (insects, seeds, fruits, and so on). The presence of a stream (Alibori River) which crosses the area makes this abundance more important. The presence of the species in the area will be permanent and will constitute an advantage for the breeders, because yellow- 
fronted canary is generally considered a resident species, even if the species may migrate short distances to stay close to the best food sources and to avoid bad weather conditions. These seasonal wanderings are particularly pronounced in the northern limits of their range (Fry and Keith, 2004; Moulton, 1993). Beyond the simple profit that the populations can make, there is, a not only cultural but also social attachment towards this bird. Recent studies by BirdLife International (2018) have shown that there are several reasons for the interest in birds and its reasons are as much cultural, artistic, philosophical as economic.

\section{Conclusion}

This study conducted in the North of Benin focused on the ethnozoology of yellow-fronted canary and revealed the importance of the traditional (medicinal and spiritual) and economic values of yellow-fronted canary for local communities. Our results suggest that the local populations have a good knowledge of yellow-fronted canary and breed the species to obtain additional income. This breeding of yellow-fronted canary is becoming an increasingly profitable and expanding activity in the northern part of Benin. In order to anticipate possible threats to the species due to the scale of commercial activity, conserving yellow-fronted canary in Benin will require considering the multiple, cultural and economic drivers of the market. The study suggested the promotion and popularization of sustainable harvesting techniques to sustain the uses of the species.

\section{References:}

1. Akpona, H. A., Mensah, G. A., \& Sinsin, B. (2007). Rôle culturel et importance économique de la loutre à cou tacheté Lutra maculicollis au Sud-Bénin. Bulletin de La Recherche Agronomique Du Bénin, 57, 52-60.

2. Bi, T. M. K., Yaokokore-Beibro, H. K., Konan, E. M., Odoukpe, S. G. K., \& Kouassi, K. P. (2015). Oiseaux comme outils d'initiation à la connaissance de la faune et du développement de la person0nalité chez les Gouro de la Marahoué, centre ouest de la Cote d'Ivoire. Journal of Applied Biosciences, 89, 8337-8347.

3. Birdlife International. (2018). Etat des populations d'oiseaux dans le monde: prenons le pouls de la planète. Species factsheet Amazilia versicolor.

4. Blendel, J., Desmet J-F. (2018). Des oiseaux et des hommes : Fonctions écologiques et services écosystémiques, Éditions Quæ.

5. Boakye, M.K., Pietersen, D.W., Kotzé, A., Dalton, D.L., \& Jansen, R. (2014) Ethnomedicinal use of African pangolins by traditional medical practitioners in Sierra Leone. J Ethnobiol Ethnomed., 76:1-10. 
6. Darghouth, M. A., \& Gharbi, M. (2011). Impact des mutations de l'environnement sur les maladies d'importance économique: Cas de l'élevage ovin en Tunisie. Options Méditerranéennes, 97(A97), 41-42.

7. de Mendiburu, F. (2020). agricolae: Statistical Procedures for Agricultural Research. https://cran.r-project.org/package=agricolae

8. Dorst, J. (1947). Le rôle disséminateur des oiseaux dans la vie des plantes. La Terre et La Vie.

9. Fry, C., S. Keith. (2004). The Birds of Africa: Volume VII. Princeton, NJ: Princeton University Press.

10. Gosselin, M., Valadon, A., Bergès, L., Dumas, Y., Gosselin, F., Baltzinger, C., \& Archaux, F. (2006). Prise en compte de la biodiversité dans la gestion forestière: état des connaissances et recommandations. irstea.

11. Guillo, D. (2015). Quelle place faut-il faire aux animaux en sciences sociales? Revue Française de Sociologie, 56(1), 135-163.

12. Habou, M. K. A., Rabiou, H., Abdou, L., Mamadou, M. I., \& Mahamane, A. (2020). Connaissances ethnobotaniques et importance socioculturelle de Balanites aegyptiaca (L.) Del. dans le Centre-Est du Niger. Afrique SCIENCE, 16(4), 239-252.

13. Kassambara, A., \& Mundt, F. (2020). factoextra: Extract and Visualize the Results of Multivariate Data Analyses. https://cran.rproject.org/package $=$ factoextra

14. Konan E. M, Yaokokore-Beibro K. H, Odoukpé K.S.G, Kouadja K .E. S. (2014). Avifaune de la ville de Yamoussoukro, Centre de Cête d'Ivoire. Journal scientifique européen, ESJ , 10 (33). https://doi.org/10.19044/esj.2014.v10n33p\%p

15. Lê, S., Josse, J., \& Husson, F. (2008). FactoMineR: A Package for Multivariate Analysis. Journal of Statistical Software, 25(1), 1-18. https://doi.org/10.18637/jss.v025.i01

16. Lougbegnon, O. T. (2015). Ecologie et connaissances ethnozoologiques de quelques espèces d'oiseaux gibiers menaces des ecosytèmes du Sud du Bénin. Université de Liège, Liège, Belgique.

17. Lougbegnon, T., Codjia, J. T. C., \& Libois, R. (2007). Biodiversité et distribution écologique de l'avifaune des plantations du sud du Bénin. Actes Du 1er Colloque de l'UAC Des Sciences Cultures et Technologies, Agronomie, 47-67.

18. Markowitz, J. E., Ivie, E., Kligler, L., \& Gardner, T. J. (2013). Longrange order in serin song. PLoS Comput Biol, 9(5), e1003052.

19. Mongne, P. (2012). In tototl in amanteca. Les oiseaux de la plumasserie aztèque. Les Dossiers Du GEMESO, 2.

20. Moulton, M. P. (1993). The All-or-none Pattern in Introduced Hawaiian Passeriforms: the Role of Competition Sustained. The 
American Naturalist, 141: 105-119.

21. R Core Team. (2020). R: A Language and Environment for Statistical Computing. https://www.r-project.org/.

22. Sanni, M.A. (2017). Langues parlées au sein du ménage et assimilation linguistique au Bénin. Cah Québécois Démogr., 46:219-39.

23. Seymour, C. L., Simmons, R. E., Joseph, G. S., \& Slingsby, J. A. (2015). On bird functional diversity: species richness and functional differentiation show contrasting responses to rainfall and vegetation structure in an arid landscape. Ecosystems, 18(6), 971-984.

24. Sinclair, I., P. Hockey. 1996. Birds of Southern Africa. Cape Town: Struik Publishers.

25. Wei, T., \& Simko, V. (2017). R package "corrplot”: Visualization of a Correlation Matrix. https://github.com/taiyun/corrplot

26. Wickham, H. (2016). ggplot2: Elegant Graphics for Data Analysis. Springer-Verlag New York. https://ggplot2.tidyverse.org

27. Yabi, F. B., Lougbegnon, T. O., \& Codjia, J. T. C. (2017). Sélection des espèces indicatrices d'oiseaux des galeries forestières au Bénin (Afrique de l'Ouest). International Journal of Biological and Chemical Sciences, 11(2), 651-669.

28. Yaokokore-Beibro, H. K., Kasse, B. K., Soulemane, O., Koue-Bi, M. T., Kouassi, P. K., \& Foua-Bi, K. (2010). Ethnozoologie de la faune mammalogique de la foret classee de badenou (Korhogo, Côted'Ivoire). Agronomie Africaine, 22(2).

29. Zanvo, S., Djagoun, S. C. A. M., Azihou, F. A., Djossa, B., Sinsin, B., \& Gaubert, Ph. (2021). Ethno-zoological and commercial drivers of the pangolin trade in Benin. Journal of Ethnobiology and Ethnomedicine 17:18 https://doi.org/10.1186/s13002-021-00446-z 